\title{
The Problem Behaviour Checklist: short scale to assess challenging behaviours
}

Peter Tyrer, Jessica Nagar, Rosie Evans, Patricia Oliver, Paul Bassett, Natalie Liedtka and Aris Tarabi

\section{Background}

Challenging behaviour, especially in intellectual disability, covers a wide range that is in need of further evaluation.

\author{
Aims \\ To develop a short but comprehensive instrument for all \\ aspects of challenging behaviour.
}

\section{Method}

In the first part of a two-stage enquiry, a 28-item scale was constructed to examine the components of challenging behaviour. Following a simple factor analysis this was developed further to create a new short scale, the Problem Behaviour Checklist (PBCL). The scale was subsequently used in a randomised controlled trial and tested for interrater reliability. Scores were also compared with a standard scale, the Modified Overt Aggression Scale (MOAS).

\section{Results}

Seven identified factors - personal violence, violence against property, self-harm, sexually inappropriate, contrary, demanding and disappearing behaviour - were scored on a 5-point scale. A subsequent factor analysis with the second population showed demanding, violent and contrary behaviour to account for most of the variance. Interrater reliability using weighted kappa showed good agreement (0.91; 95\% Cl 0.83-0.99). Good agreement was also shown with scores on the MOAS and a score of 1 on the PBCL showed high sensitivity (97\%) and specificity (85\%) for a threshold MOASscore of 4.

\section{Conclusions}

The PBCL appears to be a suitable and practical scale for assessing all aspects of challenging behaviour.

\section{Declaration of interest}

None.

\section{Copyright and usage}

(C) 2016 The Royal College of Psychiatrists. This is an open access article distributed under the terms of the Creative Commons Non-Commercial, No Derivatives (CC BY-NC-ND) licence.
There is increasing concern about problem behaviours in many forms of psychiatric care, and research has been handicapped by the absence of formal incorporation of these behaviours into diagnostic systems. Although there are several instruments that record these features, ${ }^{1}$ many have poor internal consistency and reliability or only assess one component of challenging behaviour, and others with much better psychometric properties such as the Aberrant Behaviour Checklist ${ }^{2}$ are a little long and not ideal for repeat assessments. We describe the development of a seven-item 5-point scale, the Problem Behaviour Checklist (PBCL), and tested its reliability and utility in practice.

Problem behaviours, mainly in people with intellectual disability, cover a wide range of disturbance, are a source of considerable distress to hospital staff and carers ${ }^{3,4}$ and are often expensive to manage in practice, especially at more severe levels. ${ }^{5}$ Assessment is handicapped by the absence of a satisfactory diagnostic system for recording challenging behaviour and the overlap with existing diagnoses such as personality and mood disorders. ${ }^{6}$ Thus, although the prevalence of challenging behaviours is higher than any formal diagnostic group, ${ }^{7}$ the fact that it is not recognised diagnostically makes it even more important for it to be reliably and consistently assessed. In the course of research into interventions for these problems, we recognised the need to examine the full range of behaviours reported as challenging and felt that these could be condensed into a much shorter instrument.

\section{Method}

\section{Participants}

During a randomised trial on the management of aggressive challenging behaviour ${ }^{8}$ it was observed that some forms of challenging behaviour apparently independent of aggression were not identified and these were noted. We subsequently attempted to encompass the range of all potential behaviours suitable for inclusion by close examination of two international comprehensive descriptions. ${ }^{9,10}$ Two studies were then involved in testing the scale. In the first, a field study was carried out for the World Health Organization on personality status and aggressive challenging behaviour in patients with intellectual disability in Jamaica. ${ }^{11}$ The participant population was selected from a specialist intellectual disability high school (School of Hope), a supported care home and an adult day centre for people with intellectual disabilities, all operated by the Jamaican Association on Intellectual Disabilities (JAID) in Kingston, Jamaica.

In the second study, linked to a trial of nidotherapy (details available from the author on request) in the treatment of challenging behaviour in 200 residents in care homes, the same list of behaviours was recorded for all residents at monthly intervals over the course of at least 1 year. The projects were ethically approved by the JAID and North West Wales Research Ethics Committee (10/WNo01/1).

\section{Statistical analysis}

Each of the possible challenging behaviours were scored using a 4-point scale. A key aim of the analysis was to understand the associations between the different behaviours, and factor analysis was the main tool of investigation, using a standard Varimax rotation. An individual's behaviour was considered to be associated with each factor if the factor loadings for that variable were greater than 0.5 . Separate factor analyses were performed for each of the two data-sets. The scale, called the PBCL, was created after the first analysis. 
A secondary objective was to compare the levels of agreement in the total scores of the scale in a subset of the data where the scores were determined by two different observers. During the course of the randomised trial, each of the two independent observers (A.T. and R.E.) visited at different times. A large proportion of the scores on the PBCL were zero and to avoid spurious agreement the scores were divided into five categorical groups $(0,1-3,4-6,7-11$ and $\geq 12)$. Weighted kappa was used to examine the level of agreement between observers.

Concurrent validity was also assessed by examining scores on a well-established scale for aggression, the Modified Overt Aggression Scale (MOAS). ${ }^{12}$ Receiver operating characteristic curves were used to identify the optimum cut-off point for the total score in the prediction of aggressive challenging behaviour, defined as an MOAS score of 4 . The sensitivity and specificity at this cut-off point were calculated.

\section{Results}

Thirty-seven potential types of challenging behaviour were identified from study of the literature (Table 1) but because several of these appeared to be very similar the number was reduced to 28 in the final analysis (Table 1). Factor analysis revealed seven discrete factors, personal and property violence, self-harm, sexually inappropriate behaviour, contrary behaviour, demanding and difficult behaviour, and wandering. Several of these made only a small contribution to the total variance, but at this stage it was felt they were sufficiently distinct to be included. Together these factors accounted for $91 \%$ of the variance in the Jamaican study with a Cronbach's alpha of 0.7. The first factor explained around a third of the variation in the data, with components 2 and 3 explaining more than $10 \%$ of the variation in the data. Components 4-10 explained a minor proportion of the variation. Each element was scored in terms of severity, with

Table 1 Data recorded in the Jamaican study of 37 challenging behaviour variables ${ }^{11}$

\begin{tabular}{|c|c|c|c|c|}
\hline \multirow[b]{2}{*}{ Group } & Score 0 & Score 1 & score 2 & Score 3 \\
\hline & \multicolumn{4}{|c|}{$n(\%)$} \\
\hline Verbal behaviour & $19(50)$ & $8(21)$ & $6(16)$ & $5(13)$ \\
\hline \multicolumn{5}{|l|}{ Physical } \\
\hline Pushing & $28(74)$ & $4(11)$ & $3(8)$ & $3(8)$ \\
\hline Slapping & $29(76)$ & $6(16)$ & $2(5)$ & 1 (3) \\
\hline Punching & $37(97)$ & $1(3)$ & $0(0)$ & $0(0)$ \\
\hline Kicking & $33(87)$ & $4(11)$ & $1(3)$ & $0(0)$ \\
\hline Biting & $36(95)$ & $2(5)$ & $0(0)$ & $0(0)$ \\
\hline Pulling hair & $36(95)$ & $0(0)$ & $1(3)$ & $1(3)$ \\
\hline Physical assault & $38(100)$ & $0(0)$ & $0(0)$ & $0(0)$ \\
\hline Threatening & $37(97)$ & $0(0)$ & $1(3)$ & $0(0)$ \\
\hline \multicolumn{5}{|l|}{ Destructive } \\
\hline Tearing paper & $30(79)$ & $1(3)$ & $4(11)$ & $3(8)$ \\
\hline Smashing furniture & $38(100)$ & $0(0)$ & $0(0)$ & $0(0)$ \\
\hline Damaging doors & 37 (97) & $1(3)$ & $0(0)$ & $0(0)$ \\
\hline Serious damage & $38(100)$ & $0(0)$ & $0(0)$ & $0(0)$ \\
\hline \multicolumn{5}{|l|}{ Self-harm } \\
\hline Bruising & $38(100)$ & $0(0)$ & $0(0)$ & $0(0)$ \\
\hline Scarring & 37 (97) & $1(3)$ & $0(0)$ & $0(0)$ \\
\hline Skin picking & $31(82)$ & $3(8)$ & $3(8)$ & $1(3)$ \\
\hline Scratching & $33(87)$ & $2(5)$ & $2(5)$ & $1(3)$ \\
\hline Hair pulling & $36(95)$ & $1(3)$ & $0(0)$ & $1(3)$ \\
\hline Face slapping & $37(97)$ & $0(0)$ & 1 (3) & $0(0)$ \\
\hline Biting hands & $21(64)$ & $0(0)$ & $3(9)$ & $9(27)$ \\
\hline Biting lips & $37(97)$ & $0(0)$ & $0(0)$ & $1(3)$ \\
\hline Poking & $38(100)$ & $0(0)$ & $0(0)$ & $0(0)$ \\
\hline Head banging & $38(100)$ & $0(0)$ & $0(0)$ & $0(0)$ \\
\hline Cutting & $38(100)$ & $0(0)$ & $0(0)$ & $0(0)$ \\
\hline \multicolumn{5}{|l|}{ Sexual } \\
\hline Touching & $33(87)$ & $4(11)$ & $0(0)$ & $1(3)$ \\
\hline Unwelcome kissing & $35(92)$ & $2(5)$ & $1(3)$ & $0(0)$ \\
\hline Obscene communication & $38(100)$ & $0(0)$ & $0(0)$ & $0(0)$ \\
\hline Any exposure & $38(100)$ & $0(0)$ & $0(0)$ & $0(0)$ \\
\hline Public masturbation & $38(100)$ & $0(0)$ & $0(0)$ & $0(0)$ \\
\hline Sexual assault & $34(89)$ & $4(11)$ & $0(0)$ & $0(0)$ \\
\hline \multicolumn{5}{|l|}{ Oppositional } \\
\hline Defying rules & $20(53)$ & $5(13)$ & $7(18)$ & $6(16)$ \\
\hline Refusing engage & $25(66)$ & $3(8)$ & $6(16)$ & $4(11)$ \\
\hline \multicolumn{5}{|l|}{ Demanding } \\
\hline Repeated requests & $26(68)$ & $0(0)$ & $4(11)$ & $8(21)$ \\
\hline Impatient & $28(74)$ & $1(2)$ & $2(8)$ & $3(14)$ \\
\hline \multicolumn{5}{|l|}{ Wandering } \\
\hline Wandering & $32(84)$ & $2(5)$ & $4(11)$ & $0(0)$ \\
\hline Darting & $36(95)$ & $0(0)$ & $1(1)$ & $1(1)$ \\
\hline Running away & $38(100)$ & $0(0)$ & $0(0)$ & $0(0)$ \\
\hline
\end{tabular}




\begin{tabular}{|c|c|c|c|c|c|c|c|c|c|c|}
\hline & Factor 1 & Factor 2 & Factor 3 & Factor 4 & Factor 5 & Factor 6 & Factor 7 & Factor 8 & Factor 9 & Factor 10 \\
\hline $\begin{array}{l}\text { \% variation } \\
\text { explained }\end{array}$ & 32 & 14 & 11 & 8 & 7 & 6 & 5 & $<5$ & $<5$ & $<5$ \\
\hline Verbal behaviour & & & & & & & 0.95 & & & \\
\hline \multicolumn{11}{|l|}{ Physical } \\
\hline Pushing & 0.85 & & & & & & & & & \\
\hline Slapping & 0.87 & & & & & & & & & \\
\hline Kicking & 0.81 & & & & & & & & & \\
\hline Destructive, tearing paper & & & & & & & & 0.88 & & \\
\hline \multicolumn{11}{|l|}{ Self-harm } \\
\hline Skin picking & & & & & 0.96 & & & & & \\
\hline Scratching & & & 0.59 & & & & & & & \\
\hline Biting hands & & & & 0.90 & & & & & & \\
\hline \multicolumn{11}{|l|}{ Sexual } \\
\hline Touching & & 0.69 & & & & & & & & \\
\hline Unwelcome kissing & 0.75 & & & & & & & & & \\
\hline Sexual assault & & 0.88 & & & & & & & & \\
\hline \multicolumn{11}{|l|}{ Oppositional } \\
\hline Defying rules & & & 0.54 & & & & & & & \\
\hline Refusing engage & & & 0.90 & & & & & & & \\
\hline \multicolumn{11}{|l|}{ Demanding } \\
\hline Repeated requests & & & & & & & & & 0.93 & \\
\hline Impatient & & & & & & 0.92 & & & & \\
\hline Wandering & & & & & & & & & & 0.87 \\
\hline
\end{tabular}

degree of disturbance and risk being the main driving force leading to higher scores (Table 2). The final PBCL (Appendix) therefore comprised seven problem behaviour groups with five levels of severity. Aggressive behaviour was by far the most common of these. In the second factor analysis, threatening, violent, demanding and contrary (oppositional) behaviour clustered with the aggressive factor, with sexually inappropriate and self-harming behaviour accounting for much less variance (Table 3).

\section{Comparison with scores on the MOAS}

In the randomised trial, scores for aggressive challenging behaviour were assessed using the MOAS at the same assessment using the PBCL. The MOAS is a well-established and reliable instrument for assessing aggressive behaviour in this population ${ }^{13}$ and a common threshold for aggression is a MOAS score of 4 or greater. ${ }^{8}$ The PBCL was strongly associated with this outcome, giving an area under the receiver operating characteristic curve of 0.95 (Fig. 1). A PBCL score of 1 was found to give the best prediction of this outcome, which yielded high levels of sensitivity (97\%) and specificity (85\%).

\section{Reliability}

In the randomised trial, two raters (A.T. and R.E.) assessed data from 38 participants in 7 care homes over an extended period up

\begin{tabular}{|c|c|c|}
\hline Component & Eigenvalue & $\begin{array}{l}\% \text { total } \\
\text { variation }\end{array}$ \\
\hline $\begin{array}{l}1 \text { Threatening, oppositional, demanding } \\
\text { and aggressive behaviour }\end{array}$ & 6.4 & 21.4 \\
\hline 2 Aggressive sexual behaviour & 1.9 & 6.3 \\
\hline 3 Self-harming behaviour & 1.6 & 5.4 \\
\hline $\begin{array}{l}4 \text { Hair pulling, scratching and head- } \\
\text { banging }\end{array}$ & 1.5 & 4.9 \\
\hline a. Only factor loadings $>0.5$ are reported. & & \\
\hline
\end{tabular}

to 1 year, providing a total of 407 monthly repeat assessments. In this study, a large proportion of scores on the PBCL (62\%) was zero and to avoid spurious agreement the scores were divided into five categorical groups $(0,1-3,4-6,7-11$ and $\geq 12)$. Using weighted kappa, the level of agreement was 0.91 , with the $95 \%$ confidence interval ranging from 0.83 to 0.99 . This high value indicates very good agreement between the two observers. ${ }^{14}$

\section{Discussion}

The results suggest that the PBCL is a useful measure of challenging behaviour in people with intellectual disability. It has the advantages of simplicity, shortness and repeatability, and may be of particular use in longitudinal studies. It also appears to be a comprehensive measure even though its main use in these studies has been to assess aggressive challenging behaviour and so many of the factors have correlates with aggression. The high agreement

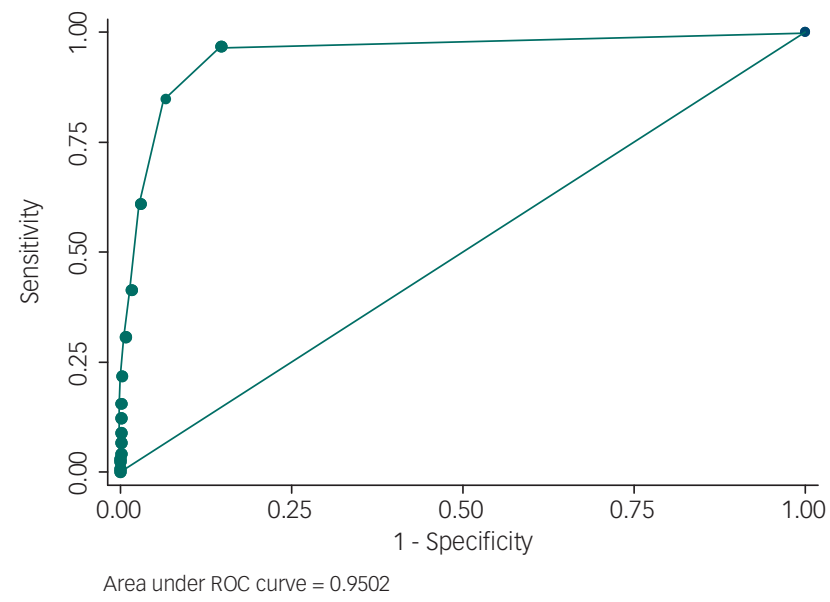

Fig. 1 Relationship between the scores of 2300 assessments for a threshold of 4 on the Modified Overt Aggression Scale and 1 on the Problem Behaviour Checklist. ROC, receiver operating characteristic 
between the MOAS and PBCL scores also adds construct validity to the scale as the MOAS is a frequently used measure in the assessment of challenging behaviour. ${ }^{15,16}$

Although the current work has been confined to people with intellectual disability it might well be extended to other populations with challenging behaviour (e.g. dementia, head injury), where direct questioning of participants may yield limited information. Its weaknesses are the relative absence of personal input by people with intellectual disability in scoring the scale. Although the high correlation between the PBCL and MOAS scales suggests that both scales are equivalent in recording challenging behaviour, the PBCL covers a broader range of items than the MOAS and so is more comprehensive. It needs further testing before the preferred populations for assessment can be chosen.

Peter Tyrer, FMedSci, Centre for Mental Health, Imperial College London, London, UK; Jessica Nagar, MSC, CRF Health, Hammersmith, London, UK; Rosie Evans, MSC, Harris Manchester College, University of Oxford, Oxford, UK; Patricia Oliver, PhD, Centre for Mental Health, Imperial College London, London, UK; Paul Bassett, MSC, FRSS, independent statistical consultant, UK; Natalie Liedtka, BSC, Western Psychiatric Institute, University of Pittsburg Medical Center, Pittsburg, California, USA; Aris Tarabi, MSC, Centre for Mental Health, Imperial College London, London, UK

Correspondence: Peter Tyrer, Centre for Mental Health, Imperial College London, 7th Floor, Commonwealth Building, Hammersmith Hospital, London W12 ONN, UK. Email: p.tyrer@imperial.ac.uk

First received 22 Oct 2015, accepted 8 Dec 2015

\section{Funding}

This research was funded by the National Coordinating Centre for Health Technology Assessment (NCCHTA) programme (project number 01/07/02), the Nicola Pigott Memorial Fund, and the National Institute for Health Research: Imperial Biomedical Research Centre. The views expressed in this publication are those of the authors and do not necessarily reflect those of the HTA programme, NIHR, NHS, or the Department of Health.

\section{Acknowledgements}

We thank Sandra O'Sullivan for her support and coordination during this study.

\section{References}

1 National Institute for Health and Care Excellence. Challenging Behaviour and Learning Disabilities: Prevention and Interventions for People with Learning Disabilities Whose Behaviour Challenges (NG11). Department of Health, 2015.
2 Tyrer F, McGrother C, Thorp CF, Donaldson M, Bhaumik S, Watson JM, et al. Physical aggression towards others in adults with learning disabilities: prevalence and associated factors. J Int Dis Res 2006; 50: 295-304.

3 Ali A, Blickwedel J, Hassiotis A. Interventions for challenging behaviour in intellectual disability. Adv Psychiatr Treat 2014; 20: 184-92.

4 Aman MG, Singh NN, Stewart AW, Field CJ. The Aberrant Behavior Checklist: a behavior rating scale for the assessment of treatment effects. Am J Ment Defic 1985; 89: 485-91.

5 Knapp M, Comas-Herrera A, Astin J, Beecham J, Pendaries C. Intellectual disability, challenging behaviour and cost in care accommodation: what are the links? Health Soc Care Community 2005; 13: 297-306.

6 Felce D, Kerr M, Hastings RP. A general practice-based study of the relationship between indicators of mental illness and challenging behaviour among adults with intellectual disabilities. J Intellect Disabil Res 2009; 53: 243-54.

7 Cooper SA, Smiley E, Morrison J, Williamson A, Allan L. Mental ill-health in adults with intellectual disabilities: prevalence and associated factors. Br J Psychiatry 2007; 190: 27-35.

8 Tyrer P, Oliver-Africano PC, Ahmed Z, Bouras N, Cooray S, Deb S, et al. Risperidone, haloperidol and placebo in the treatment of aggressive challenging behaviour in intellectual disability: a randomised controlled trial. Lancet 2008; 371: 57-63.

9 Royal College of Psychiatrists. DC-LD: Diagnostic Criteria for Psychiatric Disorders for Use with Adults with Learning Disabilities/Mental Retardation (OP48). Royal college of Psychiatrists, 2001.

10 Ministerio de Salud Pública and Hospital Psiquiátrico de la Habana. Tercer Glosario Cubano de Psiquitría. [Third Cuban Psychiatric Glossary]. Havana, 2001.

11 Tyrer $P$, Oliver $P$, Tarabi SA. Prevalence of aggressive challenging behaviours in intellectual disability and its relationship to personality status: Jamaican study. I Intellect Disabil Res 2014; 58: 1083-9.

12 Sorgi P, Ratey J, Knoedler DW, Markert RJ, Reichman M. Rating aggression in the clinical setting - a retrospective adaptation of the overt aggression scale: preliminary results. J Neuropsychiatry 1991; 3: 552-6.

13 Oliver PC, Crawford MJ, Rao B, Reece B, Tyrer P. Modified Overt Aggression Scale (MOAS) for people with intellectual disability and aggressive challenging behaviour: a reliability study. J App/ Res Intellect Disabil 2007; 20: 368-72.

14 Landis JR, Koch GG. The measurement of observer agreement for categorical data. Biometrics 1977; 33: 159-74.

15 Tsiouris JA, Kim SY, Brown WT, Cohen IL. Association of aggressive behaviours with psychiatric disorders, age, sex and degree of intellectual disability: a largescale survey. J Intellect Disabil Res 2011; 55: 636-49.

16 Unwin G, Deb S. Caregiver's concerns-quality of life scale (CC-QOLS): development and evaluation of psychometric properties. Res Dev Disabil 2014; 35: 2329-40. 


\section{Appendix}

This scale is published under the CC BY-NC-ND licence. It may be freely used for non-commercial purposes; for example, it may be copied and used by individual clinicians. For commercial uses (including, but not restricted to, pharma studies), please contact permissions@rcpsych.ac.uk.

\section{Problem Behaviour Checklist}

Please assess each behaviour over the past week/month

Patient Code/Identifier: Date:
This is a hierarchical scale - the higher levels are assumed to contain all the elements beneath it, so if a person scores 4 on an item, the scores below that are disregarded. However, when the frequency or intensity of a behaviour becomes very great (e.g. repeated threatened violence or minor assault) to the point where it leads to major concerns to others the score may be raised by 1 (but no more). In deciding this please note the general requirements for the problem behaviour score at the top of the scale.

When making the assessment use as many informants as possible to cover all settings and observations.

Assessor:

\begin{tabular}{|c|c|c|c|c|c|}
\hline & $\begin{array}{c}\text { Behaviour absent } \\
0\end{array}$ & $\begin{array}{l}\text { Minor and often } \\
\text { frequent behaviour but } \\
\text { little disruption to } \\
\text { others } \\
1\end{array}$ & $\begin{array}{l}\text { Moderate problem } \\
\text { behaviour creating } \\
\text { distress and disruption } \\
2\end{array}$ & $\begin{array}{l}\text { Serious problem behaviour } \\
\text { leading to major concerns } \\
\text { and risk to others } \\
3\end{array}$ & $\begin{array}{l}\text { Extreme behaviour leading } \\
\text { to threat of loss of life or } \\
\text { permanent injury and } \\
\text { damage } \\
4\end{array}$ \\
\hline $\begin{array}{l}\text { Personal violence } \\
\text { Score (0-4): }\end{array}$ & $\begin{array}{l}\text { No verbal abuse } \\
\text { and no form } \\
\text { of violent } \\
\text { behaviour }\end{array}$ & Verbal abuse & $\begin{array}{l}\text { Threatened violence } \\
\text { or minor assault with } \\
\text { no lasting injury or } \\
\text { breaking of skin } \\
\text { (e.g. slapping, pushing) }\end{array}$ & $\begin{array}{l}\text { Physical assault with } \\
\text { likelihood of, or } \\
\text { consequent, injury with } \\
\text { temporary handicap or } \\
\text { psychological damage } \\
\text { (e.g. bruising, fear } \\
\text { avoidance) }\end{array}$ & $\begin{array}{l}\text { Physical assault } \\
\text { with permanent or } \\
\text { life-threatening injury } \\
\text { (e.g. poking through } \\
\text { eyes, stabbing, loss of } \\
\text { consciousness) }\end{array}$ \\
\hline $\begin{array}{l}\text { Property violence } \\
\text { Score (0-4): }\end{array}$ & No damage & $\begin{array}{l}\text { Minor damage with } \\
\text { no serious } \\
\text { consequences } \\
\text { (e.g. tearing paper) }\end{array}$ & $\begin{array}{l}\text { Moderate damage with } \\
\text { need for minor repairs } \\
\text { (e.g. breaking front } \\
\text { window) }\end{array}$ & $\begin{array}{l}\text { Serious damage requiring } \\
\text { major property repairs or } \\
\text { creating some risk to } \\
\text { others }\end{array}$ & $\begin{array}{l}\text { Very serious damage with } \\
\text { threat to life or limb } \\
\text { (e.g. arson, floor collapse) }\end{array}$ \\
\hline $\begin{array}{l}\text { Self-harm } \\
\text { Score (0-4): }\end{array}$ & No self-harm & $\begin{array}{l}\text { Minor harm with no } \\
\text { breaking of skin (e.g. } \\
\text { minor head banging) }\end{array}$ & $\begin{array}{l}\text { Moderate self-harm } \\
\text { with breaking of skin, } \\
\text { scarring or small } \\
\text { overdose but no } \\
\text { long term }\end{array}$ & $\begin{array}{l}\text { Serious self-harm with } \\
\text { potential of risk of death } \\
\text { (e.g. swallowing bleach, } \\
\text { poking own eyes) }\end{array}$ & $\begin{array}{l}\text { Suicidal act or violent } \\
\text { self-harm leading to death } \\
\text { or permanent handicap }\end{array}$ \\
\hline $\begin{array}{l}\text { Sexually } \\
\text { inappropriate } \\
\text { behaviour } \\
\text { Score }(0-4) \text { : }\end{array}$ & $\begin{array}{l}\text { No inappropriate } \\
\text { behaviour }\end{array}$ & $\begin{array}{l}\text { Obscene gestures or } \\
\text { sexually abusive } \\
\text { comments }\end{array}$ & $\begin{array}{l}\text { Touching, fondling and } \\
\text { kissing (non-violent but } \\
\text { bodily contact) }\end{array}$ & $\begin{array}{l}\text { More serious sexual } \\
\text { assault with bodily } \\
\text { contact or indecent } \\
\text { exposure }\end{array}$ & $\begin{array}{l}\text { Violent sexual assault } \\
\text { including rape and } \\
\text { coercive sexual contact }\end{array}$ \\
\hline $\begin{array}{l}\text { Contrary behaviour } \\
\text { Score (0-4): }\end{array}$ & $\begin{array}{l}\text { No contrary } \\
\text { behaviour }\end{array}$ & $\begin{array}{l}\text { Verbal negativity and } \\
\text { initial refusal to obey } \\
\text { instructions }\end{array}$ & $\begin{array}{l}\text { Oppositional behaviour, } \\
\text { single or recurrent, } \\
\text { creating problems for } \\
\text { others but not serious } \\
\text { disruption }\end{array}$ & $\begin{array}{l}\text { Severe contrary } \\
\text { behaviour leading to } \\
\text { potential danger to health } \\
\text { and welfare (e.g. refusal } \\
\text { to take prescribed } \\
\text { medicine when essential; } \\
\text { deliberate flooding of } \\
\text { bathroom) }\end{array}$ & $\begin{array}{l}\text { Dangerous oppositional } \\
\text { behaviour causing } \\
\text { problems for health and } \\
\text { welfare (e.g. refusal to } \\
\text { leave burning building, } \\
\text { running into path of car } \\
\text { when asked to walk on } \\
\text { pavement) }\end{array}$ \\
\hline $\begin{array}{l}\text { Demanding } \\
\text { behaviour } \\
\text { Score }(0-4) \text { : }\end{array}$ & $\begin{array}{l}\text { No demanding } \\
\text { behaviour }\end{array}$ & $\begin{array}{l}\text { Frequent need for } \\
\text { attention but little } \\
\text { disruption }\end{array}$ & $\begin{array}{l}\text { Threatening and } \\
\text { disturbing demanding } \\
\text { behaviour that disrupts }\end{array}$ & $\begin{array}{l}\text { Violent demanding } \\
\text { behaviour that distresses } \\
\text { others, not only at the } \\
\text { time, but subsequently }\end{array}$ & $\begin{array}{l}\text { Violent demands on } \\
\text { others that are a serious } \\
\text { threat to psychological } \\
\text { health and function } \\
\text { (e.g. stalking) }\end{array}$ \\
\hline $\begin{array}{l}\text { Disappearing } \\
\text { behaviour } \\
\text { Score (0-4): }\end{array}$ & $\begin{array}{l}\text { Does not disappear } \\
\text { and never goes } \\
\text { away without } \\
\text { warning }\end{array}$ & $\begin{array}{l}\text { Absent minded, gets } \\
\text { lost easily, or tends to } \\
\text { drift away from group } \\
\text { and has to be } \\
\text { recalled }\end{array}$ & $\begin{array}{l}\text { Needs constant } \\
\text { supervision to avoid } \\
\text { getting lost or } \\
\text { running off }\end{array}$ & $\begin{array}{l}\text { Darting and other } \\
\text { deliberate movements } \\
\text { that may put person in } \\
\text { danger (e.g. runs across } \\
\text { main road) }\end{array}$ & $\begin{array}{l}\text { Complete disappearance } \\
\text { over long distance with } \\
\text { need to search for person } \\
\text { with help of other } \\
\text { agencies (e.g. police) }\end{array}$ \\
\hline
\end{tabular}

